\title{
BUREAUCRATIC ACCOUNTABILITY FOR REGULATORY DECISIONS: COMMENT ON LUPIA AND MCCUBBINS
}

\author{
KATHLEEN BAWN*
}

\section{INTRODUCTION}

Professors McCubbins and Schwartz coined the term "fire alarm" when arguing that Congress's apparent lack of effort in directly monitoring bureaucratic activity is not evidence of lack of control. ${ }^{1}$ Congress can rely on interest groups and constituents to sound the alarm about agency misbehavior, and this alone will deter some agency drift. Moreover, in establishing an agency's administrative arrangements, Congress can lower the costs of agency access for specific groups, enfranchising the interests it wants to help. Problems exist with relying on fire alarms, however. Fire alarms are, by definition, groups affected by the agency's decisions. Their reports about agency decisions are not necessarily credible.

Professors Lupia and McCubbins address this credibility problem in their model of the internal logic of fire alarms. They show that information about agency decisions can come from multiple sources that may or may not be credible. Sources may be credible for different reasons: because they take costly actions; because they face penalties for lying (they have reputations to maintain); or because their preferences are known to coincide with the principal's. ${ }^{2}$ Lupia and McCubbins's model is quite general, illustrating the variety of ways that institutional arrangements provide Congress with information about agency decisions.

The authors make an important step toward modeling the design of bureaucratic accountability. They show how the amount of usable information Congress receives depends on institutional features, such as how difficult it is for a potential fire alarm to sound the alarm. These institutional features are decided by Congress in the course of legislating administrative arrangements. A true model of bureaucratic design would imbed Lupia and McCubbins's model of the informational consequences of bureaucratic institutions into a model of congressional decisionmaking about those institutions. The existing model in its general form may be too complex to be the second stage of a model of

\footnotetext{
Copyright $\odot 1994$ by Law and Contemporary Problems

* Assistant Professor of Political Science, University of California at Los Angeles.

1. Mathew McCubbins \& Thomas Schwartz, Congressional Oversight Overlooked: Police Patrols versus Fire Alarms, 28 AM. J. POL. SCI. 165, 166 (1984).

2. Arthur Lupia \& Mathew D. McCubbins, Designing Bureaucratic Accountability, 57 LAW \& CONTEMP. PROBS. 91 (Winter 1994).
} 
institutional choice. In particular, the information revealed depends on how the ideal points of Congress, the agency, and the information sources are situated.

This comment discusses a simple sub-case of Lupia and McCubbins's general model, corresponding to a particular configuration of ideal points. It is somewhat different from the sub-case Lupia and McCubbins use to develop their model. While the authors' sub-case is a good one for demonstrating the intuition behind the model, the one discussed below may, for two reasons, be more appropriate for addressing questions about designing regulatory agencies. First, it is relatively simple. Second, it corresponds to the political environment characteristic of regulatory policymaking.

\section{II}

\section{GENERAL FRAMEWORK}

The essential features of Lupia and McCubbins's general framework are as follows. Policies are proposed by the agency and can be blocked by Congress. Because of the agency's informational advantage, however, Congress does not know the consequences of the agency's proposed policy. Interest groups can make reports to Congress about the agency's proposal. Making a proposal or a report may or may not be costly. Congress does not know the agency's ideal point. Other actors may or may not know each others' preferences. It may or may not be costly for interest groups to lie or to find out the consequences of the agency's proposal.

To illustrate the general model, Lupia and McCubbins consider the following sub-case. Congress wants policy to change in the opposite way from what the agency wants. Interest Group One has the same preferences as Congress. Group Two's ideal point is the status quo. Everybody knows the location of the status quo. Congress does not know the preferences of the agency or of the group that shares its preferences. Everyone knows that Group Two likes the status quo best. Group Two must exert costly effort to find out the consequences of the agency's offer; Group One finds out costlessly. The latter group pays a penalty for lying to Congress about the agency's proposal.

The difference in costs faced by the two interest groups has a natural interpretation as the difference between organized and unorganized interests. The organized interest has enough expertise to understand the consequences of the agency's proposal. Because it expects to have a stake in future policy decisions, it suffers a penalty if it damages its reputation by lying. The unorganized interest must invest in learning if it wants to understand the agency's proposal, but it does not have a reputation to worry about.

\section{III}

\section{Whose PrefERences Are MORE EXTREME?}

This scenario with one organized and one relatively disorganized interest group describes regulatory politics. The two information sources are the two 
groups affected by regulatory decisions: the beneficiaries and those who pay the costs. These groups could represent organized producers and unorganized consumers, polluters and those who suffer from pollution, or existing firms and potential entrants. The characterization of the interest groups in Lupia and McCubbins's sub-case is thus appropriate for thinking about the design of regulatory agencies.

Consider the arrangement of ideal points, however. In Lupia and McCubbins's sub-case, the support of the distribution from which the information sources' ideal point are drawn lies between the ideal points of Congress and the agency. However, if the two interest groups represent the winners and losers from regulatory decisions, the ideal points of Congress and the agency will be less extreme than those of the interest groups. Legislators' preferences derive from the interests of constituents and support groups because of the desire to be re-elected. ${ }^{3}$ Agency preferences similarly derive from external sources-the preferences of elected officials and interest groups. ${ }^{4}$ Because legislators represent diverse constituencies and agencies face conflicting preferences, the ideal points of Congress and the agency will almost always lie in between those of the two fire alarms. An additional reason why Congress's ideal policy is unlikely to be more extreme than the interest groups is that Congress is a group of individuals whose collective decision reflects bargaining and compromise.

\section{IV}

\section{BELIEFS About INTEREST GRoUP PREFERENCES}

If we continue to consider Congress's two outside sources of information to be the potential winners and losers from regulatory decisions, we can narrow the relevant sub-cases in terms of information structure as well as preference configurations. As noted above, the first point is that interest group preferences will generally be more extreme than an agency's or Congress's. The second point is that if we know this, so does Congress. For this reason, sub-cases in which Congress associates positive probability with the interest group having less extreme preferences than itself are not often relevant to the accountability of regulatory agencies.

In fact, Congress is less likely to be uncertain about interest group preferences than about the status quo. Given that legislative preferences on a policy dimension derive from how the policy affects interest groups and constituents, legislators usually know the preferences of any group they care about helping. On the other hand, if status quo is the outcome of current policy, legislators may not know its precise location. For example, Congress is less likely to be uncertain about the Sierra Club's or the National Coal Association's

3. David Mayhew, Congress: The Electoral Connection (1974).

4. See Roger Noll, The Political Foundations of Regulatory Policy in CONGRESs: STRUCTURE AND Policy 462, 479-82 (Mathew D. McCubbins \& Terry Sullivan eds., 1987); see also WESLEY MAGAT ET




preference on the dimension of stringency of air quality standards than it is about the precise consequences of current policy.

\section{$\mathrm{V}$ \\ CONCLUSION}

Lupia and McCubbins's model shows how Congress can gain information about agency decisions from outside sources of information. The amount of information transmitted depends not only on institutional parameters, such as the costs of making proposals and reports, but also on the configuration of ideal points. For this reason, the model's predictions about how Congress tries to design bureaucratic accountability will only be as good as the assumptions about the preferences of the players. The most promising configurations of preferences for Lupia and McCubbins to consider are those in which the ideal points of Congress and the agency are known to lie between those of the fire alarms. 